\title{
Effect of Action Against Hunger intervention on crop farmers' production level in climate change affected areas of Kita, Kayes region of Mali
}

\author{
MAHAMADOU Y. DEMBELE, AKINBILE L. A. AND AMINU O. O. \\ Department of Agricultural Extension and Rural Development, University of Ibadan, Nigeria \\ nibanajah1@gmail.com, lakinbile@yahoo.com, funmiaminu83@gmail.com
}

\begin{abstract}
Cereal crop production in Kita, Kayes region of Mali is on a serious decline due to climate change effects. Hence, Action Against Hunger (AAH) intervention was launched towards addressing climate change effects in Kita in view of increasing level of agricultural production and standard of living of the local farmers. Therefore, the study examined the effect of AAH intervention on crop farmers' production. A multi-stage sampling technique was used to select 223 from 1,226 beneficiaries of AAH intervention in Kita circle while 101 non-beneficiaries were randomly selected from Bafoulabé circle where no similar projects were going on. Data collected were subjected to statistical analysis using frequency counts, mean, charts and percentages. Chi-square and Pearson Product Moment Correlation were used to determine relationships between relevant variables. T-test was used to determine significant difference between beneficiaries' level of production before and after intervention and between beneficiaries' and non-beneficiaries' level of production after intervention. Multiple regression analysis was used to determine significant contribution of the independent variables to dependant variable. Attitude towards AAH intervention $(\mathrm{r}=0.198, \mathrm{p}<0.05)$ had significant relationship with change in beneficiaries' production. Significant difference existed between level of production of beneficiaries before $\overline{\mathrm{X}}=2138.6748$ and after $\overline{\mathrm{X}}=2445.6098$ intervention $(\mathrm{t}=11.929, \quad \mathrm{p}<0.01)$ but the level of change was low (65.0\%). Difference also exists between beneficiaries and non-beneficiaries level of production. Major determinants
\end{abstract}


of change in level of production were monthly income $(\beta=0.499, \quad \mathrm{p}<0.01)$ and farm size $(\beta=0.374, \mathrm{p}<0.01)$.

Keywords: climate change - intervention - production level - beneficiaries - non-beneficiaries

\section{Introduction}

Agriculture constitutes the backbone of most African economies. It is the largest contributor to GDP, the biggest source of foreign exchange, accounting for about $40 \%$ of the continent's foreign currency earnings and the main generator of saving and tax revenue (Shah et al., 2008). In an African country like Mali rain-fed agriculture is considered the most vulnerable sector to changes in climate and the potential impacts of climate change on agriculture are highly uncertain. HLPE (2012) reported that agriculture contributes to climate change by anthropogenic emissions of greenhouse gases and by the conversion of non-agricultural land such as forests into agricultural land. Impacts of climate change on crop production might be felt primarily through changes in crop yields, water availability, pests and diseases, animal health and other biophysical factors (FAO, 2012). SEA (2013) noted that climate change threatens to reverse progress towards sustainable development and threatens lives and livelihoods around the globe, either directly through its physical impacts or as a compounding factor towards existing vulnerabilities.

Thus, global food challenge appears to be even more prominent, given that efforts related to the Millennium Development Goals (especially those related to the reduction of hunger and poverty) have not achieved the expected results in poorer nations of the world. The Food and Agriculture Organization reported that in 2011-2013, at least 842 million people in the world, or nearly one in eight people, were chronically hungry. Sub-Saharan Africa remains the region with the highest prevalence of under nutrition, with nearly one in four people undernourished. FAO (2008) reported that over 29\% of Mali's population is malnourished. Mali's low economic development, limited land 
suitable for agriculture, and poverty make the country particularly vulnerable to climate change.

In order to mitigate climate change effects on cereal crop production while at the same time adapting to its effects among cereal crop farmers in Mali, the Action Against Hunger intervention was embarked upon in 2013 in Kayes region of Mali. One of the mandate of AAH intervention is combating household food resilience in climate change affected areas of Mali. It aims to increase the resilience of populations to food crises and to prevent under nutrition in Mali. AAH focuses on sustainable agriculture that places communities at the centre of decisions.

However, there is dearth of data on the current level of production of beneficiaries before and after AAH intervention program that can help ascertain if intervention had actually bring about positive change in the level of production of the beneficiaries. There is also the need for statistical documentation of farmers' attitude towards the intervention. Hence, this study examines the effect of AAH intervention on agricultural production of beneficiaries in climate change affected areas of Kayes' region, Mali.

\section{Methodology}

Kayes region of Mali is located between longitude $14^{\circ} 27^{\prime}$ north of the

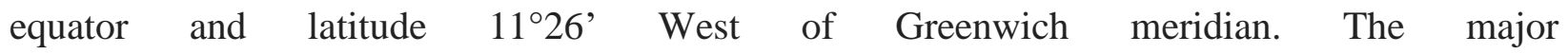
occupation was crop farming and trading. The population of this study consists of beneficiaries and non-beneficiaries of AAH intervention involved in cereal crop production. A multi-stage sampling technique was used to select respondents. For beneficiaries, Kita was purposively selected because it is the circle that benefitted from AAH intervention. Two communes with 14 villages were purposively selected from where 5 villages (30\%) were randomly selected. Ten percent of beneficiaries were randomly selected from each village to give 123 beneficiaries. Non-beneficiaries were selected from Bafoulabé circle because there are no similar projects going on in the circle. Two communes with 51 villages were randomly selected from where 5 
villages (10\%) were sampled. From each village, $15 \%$ cereal farmers were randomly selected to give 101 non-beneficiaries. Hence, the total number of respondents for this study was 224. Data was collected using interview schedule and analysed using both descriptive such as frequency counts, percentages, mean, bar charts and inferential statistics such as chi-square. PPMC, t-test and linear regression analysis.

\section{Results and discussion}

\section{Socio-economic characteristics of respondents}

Table 1 reveals $33.3 \%$ and $30.1 \%$ of beneficiaries are within 34-49 and 50-65 years respectively with a mean age of $44.18 \pm 14.49$ years. This implies that both young and old are well represented in AAH intervention. According to Sangotegbe (2011), age is very important when it comes to involvement of farmers in farming activities. Beneficiaries who were males (56.9\%) were more than females $(43.1 \%)$ implying that gender equality was ensured during the selection of respondents. This result is consistent with IFPRI (2010) that the percentage of male farmer participants in agricultural programs is higher than female participants. Majority of the beneficiaries (93.5\%) were married indicating that respondents are responsible adults. Oladoja et al (2008) stated that marriage confers some level of responsibility and commitment on individual who are married. Beneficiaries were all Muslims indicating the dominance of Islamic religion in the study area. Majority of the beneficiaries (87.0\%) lack formal education which implies high level of illiteracy among beneficiaries. The level of income derived by beneficiaries was found to be low (62.6\%) which could limit expansion of crop production, adoption of new techniques/technologies and sustainability of new projects. Majority of the beneficiaries cultivate farm sizes between 14 ha $(67.5 \%)$ with mean farm size of $3.86 \pm 2.83$ ha indicating most beneficiaries are small scale farmers with limited production and might not have capacity for large scale production. Hence, opportunities that can bring about increase in production might be hindered owning to their small farm 
holdings. Major crops grown by beneficiaries were sorghum (91.9\%), groundnut $(87.8 \%)$ and maize $(66.7 \%)$.

Table 1 Distribution of socio-economic characteristics of beneficiaries $(\mathrm{N}=123)$

\begin{tabular}{|c|c|c|c|c|}
\hline Age & Frequency & Percentage & Mean & Standard dev. \\
\hline $18-33$ & 34 & 27.6 & 44.18 & 14.487 \\
\hline $34-49$ & 41 & 33.3 & & \\
\hline $50-65$ & 37 & 30.1 & & \\
\hline $66-81$ & 11 & 8.9 & & \\
\hline \multicolumn{5}{|l|}{ Sex } \\
\hline Male & 70 & 56.9 & & \\
\hline Female & 53 & 43.1 & & \\
\hline \multicolumn{5}{|c|}{ Marital status } \\
\hline Single & 1 & 0.8 & & \\
\hline Married & 115 & 93.5 & & \\
\hline Widowed & 7 & 5.7 & & \\
\hline \multicolumn{5}{|l|}{ Education } \\
\hline No formal & 107 & 87.0 & & \\
\hline Alphabetise & 1 & 0.8 & & \\
\hline Arabic & 5 & 4.1 & & \\
\hline Primary & 7 & 5.7 & & \\
\hline Secondary & 3 & 2.4 & & \\
\hline \multicolumn{5}{|c|}{ Monthly income } \\
\hline Low & 77 & 62.6 & $36,369.46$ & $30,622.49$ \\
\hline High & 46 & 37.4 & & \\
\hline \multicolumn{5}{|c|}{ Farm size (ha) } \\
\hline $1-4$ & 83 & 67.5 & 3.860 & 2.8315 \\
\hline $5-8$ & 32 & 26.0 & & \\
\hline $9-12$ & 5 & 4.1 & & \\
\hline $13-16$ & 2 & 1.6 & & \\
\hline $17-20$ & 1 & 0.8 & & \\
\hline \multicolumn{5}{|c|}{ Crops grown } \\
\hline Sorghum & 113 & 91.9 & & \\
\hline Groundnut & 108 & 87.8 & & \\
\hline Maize & 82 & 66.7 & & \\
\hline
\end{tabular}

\section{Attitude of beneficiaries toward AAH intervention}

Figure 1 shows that more than half of the beneficiaries (56.0\%) had favourable attitude toward AAH intervention while $44.0 \%$ had unfavourable attitude. This result indicates that AAH intervention met the felt need of the beneficiaries. 


\section{Level of attitude}

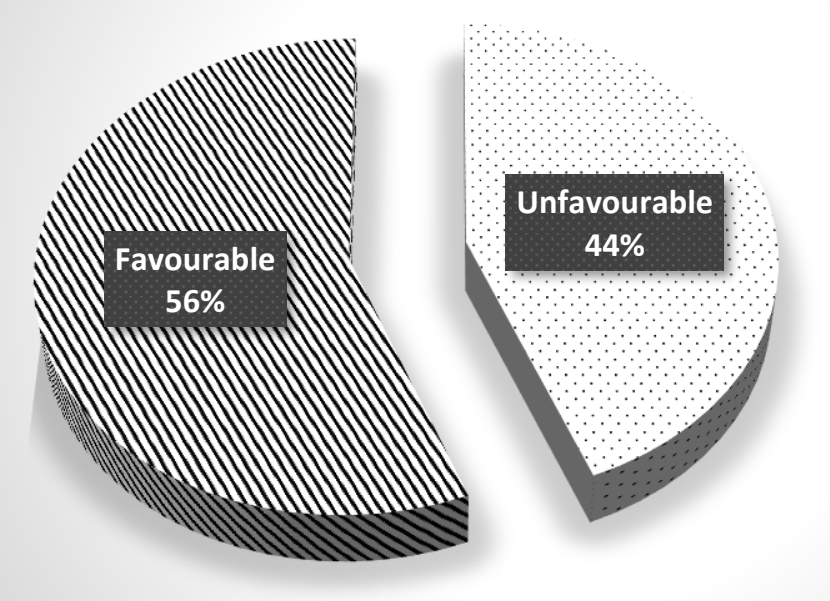

. Unfavourable

S Favourable

Figure 1: Beneficiaries' attitude towards intervention

\section{Beneficiaries sources of information on AAH intervention}

The result on Table 2 reveals that NGO and friends/relatives ranked first and second respectively among the various sources of information assessed. This result implies that information on AAH intervention is majorly from the organisation itself.

Table 2: Beneficiaries sources of information on AAH intervention

\begin{tabular}{lcccccccc}
\hline \multirow{2}{*}{ Sources } & \multicolumn{2}{c}{ Never } & \multicolumn{9}{c}{ Sometimes } & \multicolumn{2}{c}{ Always } & \multicolumn{2}{c}{} \\
& Freq. & $\%$ & Freq. & $\%$ & Freq. & \% & Mean & Rank \\
\hline Radio & 93 & 75.6 & 30 & 24.4 & - & - & 0.24 & $5^{\text {th }}$ \\
Television & 122 & 99.2 & 1 & 0.8 & - & - & 0.10 & $6^{\text {th }}$ \\
Farmers' association & 86 & 69.9 & 35 & 28.5 & 2 & 1.6 & 0.32 & $4^{\text {th }}$ \\
Extension agents & 120 & 97.6 & 2 & 1.6 & 1 & 0.8 & 0.03 & $7^{\text {th }}$ \\
NGOs & 1 & 0.8 & 90 & 73.2 & 32 & 26.0 & 1.25 & $1^{\text {st }}$ \\
Friends/relatives & 8 & 6.5 & 113 & 91.9 & 2 & 1.6 & 0.95 & $2^{\text {nd }}$ \\
Bill boards & 117 & 95.1 & 6 & 4.9 & - & - & 0.50 & $3^{\text {rd }}$ \\
\hline
\end{tabular}

Beneficiaries' level of production from 2010-2012

Figure 2 shows that the percentage of beneficiaries with low level of production in year $2010(70.7 \%)$ is greater than those with low level of 
production in year 2011 (55.9\%) and 2012 (66.7\%). Beneficiaries who had high level of production in year 2011 (43.1\%) are greater than those with high production level in year 2012 and 2010. This implies that beneficiaries experienced increase in their production level in year 2011 $\begin{array}{llll}(\bar{X}=2325.7886 \pm 1813.85360) & \text { compare } & \text { to } & \text { year }\end{array}$ $(\bar{X}=1873.2683 \pm 1789.75004)$ and $2010(\bar{X}=2216.6748 \pm 1852.16971)$.

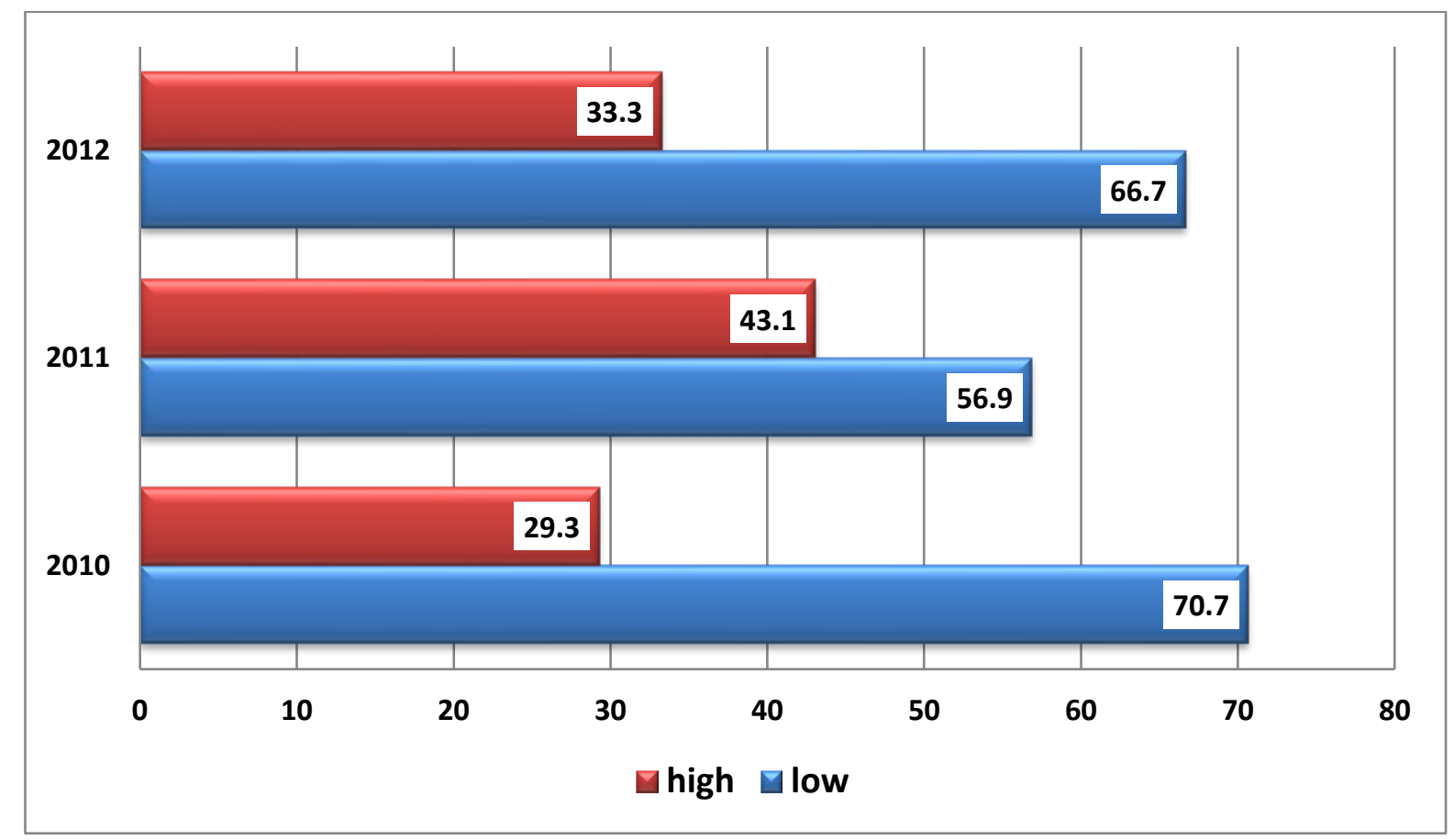

Figure 2: Beneficiaries' level of production from year 2010-2012

\section{Respondents' level of production in tons from 2014-2016}

Figure 3 shows that the percentage of beneficiaries with low level of production in year 2014 (69.9\%), 2015 (68.3\%) and 2016 (65.9\%) is greater than those with high level of production in the same year. It was observed in this study that despite AAH intervention in the study area, higher percentage of beneficiaries still experienced low level of production. The level of production was also found to be low among non-beneficiaries between 20142016. 


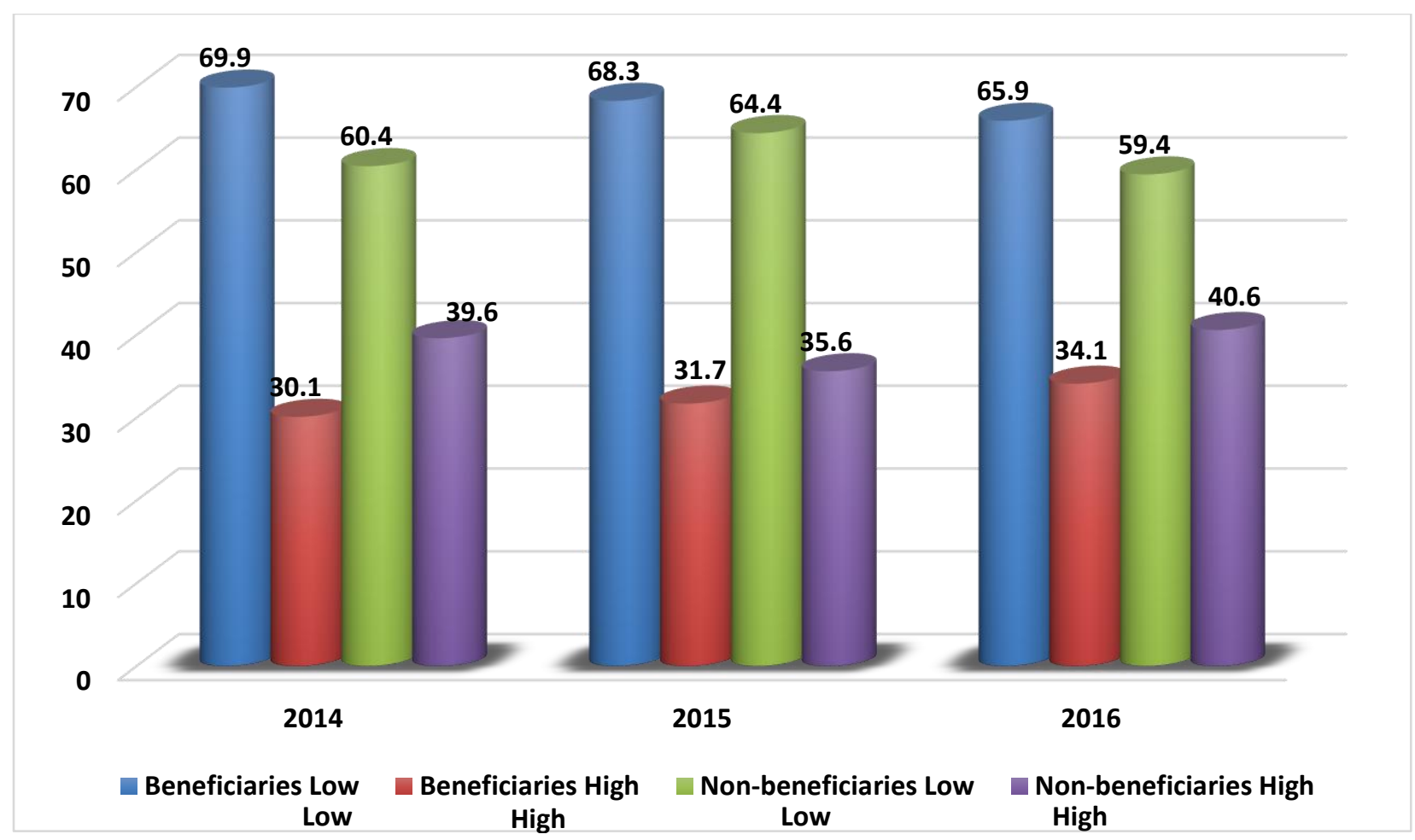

Figure 3: Respondents' level of total production from year 2014-2016

\section{Beneficiaries' level of change in production (tons) before and after intervention}

Figure 4 reveals that $65.0 \%$ of beneficiaries had low change in production level while $35.0 \%$ experienced high level of change with a mean of $306.935 \pm 622.063$ tonnes. This implies that AAH intervention had not brought about optimal increase in beneficiaries' production level. The low level of change in production can be attributed to constraints such as inadequate labour and capital associated with some techniques disseminated to beneficiaries during the $\mathrm{AAH}$ intervention as found during the course of this survey. 


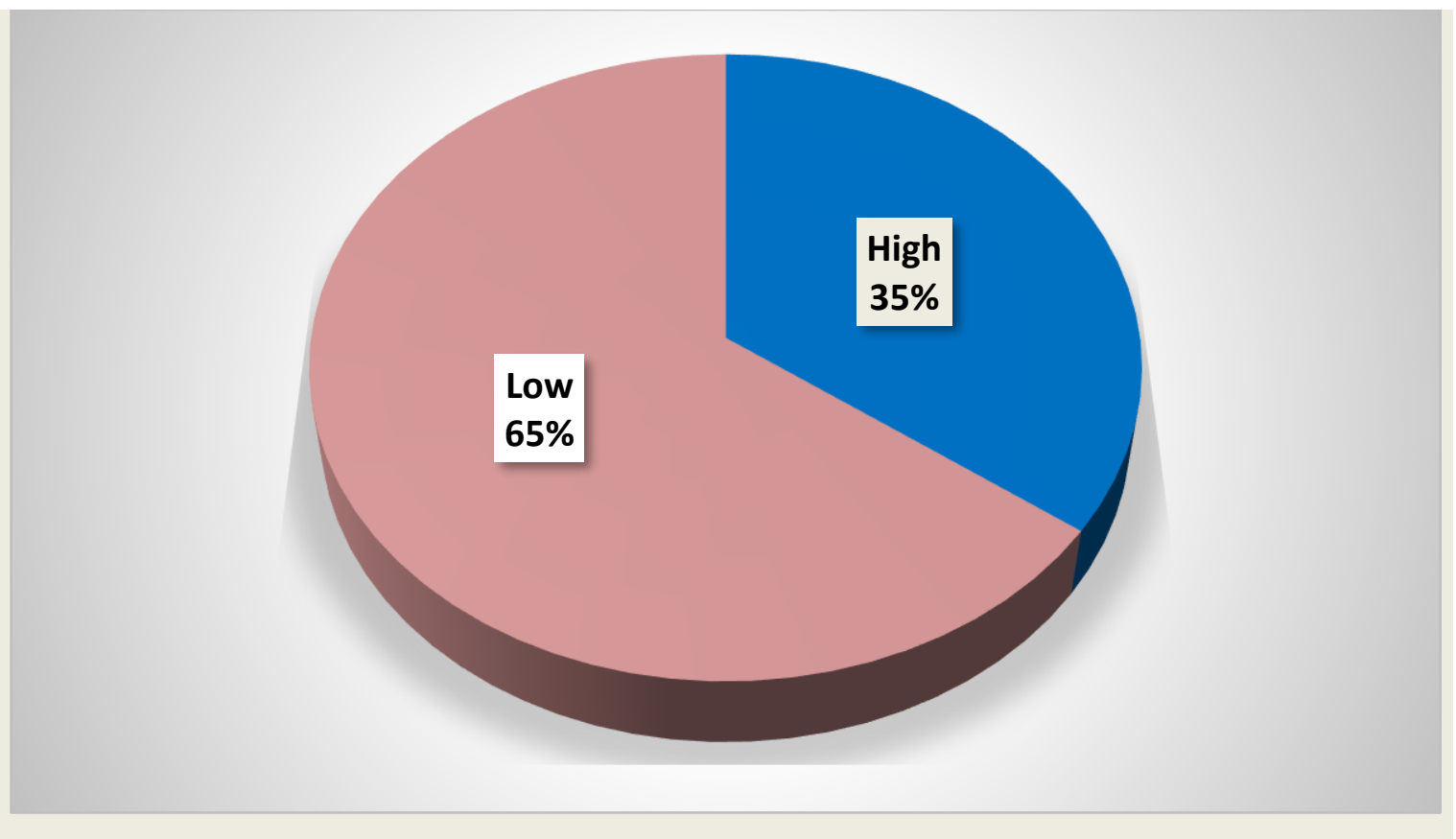

Figure 4: Beneficiaries' level of change in production (tons).

\section{Hypotheses testing}

\section{Test of relationship between beneficiaries' attitude and change in production level}

Table 4 shows that significant relationship exists between beneficiaries' attitude towards intervention and change in production level $(\mathrm{r}=0.198, \mathrm{p}>0.05)$. This implies that beneficiaries' attitude influence change in production experienced.

Table 4: PPMC analysis between beneficiaries' attitude and change in production level

\begin{tabular}{llll}
\hline Variables & r value & p value & Decision \\
\hline Attitude & 0.198 & -0.028 & Significant
\end{tabular}

Test of difference in production level of beneficiaries before and after intervention.

Table 5 reveals that significant difference exists between production level of beneficiaries before and after intervention $(\mathrm{t}=11.929, \mathrm{p}<0.01)$. This indicates that the quantity produced by beneficiaries after intervention is greater than the quantity produced before intervention, though the increase in yield 
experienced by beneficiaries was low owing to factors beyond their control as found out in this study. Such factors include health related problems and labour/finance associated issues.

Table 5: One-Sample t-test between beneficiaries' production level before and after intervention

\begin{tabular}{cccccc} 
Production level & Mean & Standard Dev. & t-value & p-value & Decision \\
\hline Before & 2138.675 & 1788.181 & 11.929 & 0.000 & $\mathrm{~S}$ \\
After & 2445.609 & 2273.64304 & & & \\
\hline
\end{tabular}

S=Significant

Test of difference in production level of beneficiaries and non-beneficiaries after intervention

Table 6 shows that no significant difference exists between beneficiaries and non-beneficiaries level of production $(\mathrm{t}=-1.028, \mathrm{p}>0.05)$. It can be inferred that the AAH intervention had not bring about substantial increase in beneficiaries' production level that could have given them an edge over nonbeneficiaries.

Table 6: Independent sample t-test between beneficiaries and non-beneficiary's production level

\begin{tabular}{lccrrrr}
\hline Respondents & N & Mean & Standard Dev. & t-value & p-value & Decision \\
\hline Beneficiary & 123 & 2445.609 & 2273.643 & -1.028 & 0.250 & NS \\
Non- beneficiary & 101 & 2735.957 & 1877.1086 & & & \\
\hline
\end{tabular}

NS=Not Significant

\section{Contribution of independent variables to beneficiaries' production level after intervention}

Table 7 indicates that monthly income $(\beta=0.499 . \quad \mathrm{p}<0.01)$ and farm size $\quad(\beta=0.374, \quad \mathrm{p}<0.01)$ were significant predictors of change in production experienced by beneficiaries. The analysis indicated R2 value of 0.859 which implies that independent variables can explain $85.9 \%$ of the beneficiaries' change in production. 
Table 7: Contribution of independent variables to beneficiaries' change in production level

\begin{tabular}{lrrrrr}
\hline & \multicolumn{2}{c}{$\begin{array}{c}\text { Unstandardized } \\
\text { Coefficients }\end{array}$} & $\begin{array}{c}\text { Standardized } \\
\text { Coefficients }\end{array}$ & & \\
& B & Std. Error & Beta & t value & p-value \\
\hline (Constant) & 863.513 & 7461.277 & & 0.116 & 0.908 \\
Age & -41.927 & 59.157 & -0.088 & -0.709 & 0.480 \\
Sex & -682.892 & 674.749 & -0.049 & -1.012 & 0.314 \\
Household size & 7.674 & 34.453 & 0.012 & 0.223 & 0.824 \\
Monthly income & 0.106 & 0.016 & 0.499 & 6.614 & $0.000^{* *}$ \\
Years of farming experiences & 47.567 & 59.545 & 0.095 & 0.799 & 0.426 \\
Farm size & 873.772 & 164.396 & 0.374 & 5.315 & $0.000^{* *}$ \\
Attitude toward intervention & -21.143 & 94.160 & -0.009 & -0.225 & 0.823 \\
Source of information score on & 383.273 & 375.012 & 0.054 & 1.022 & 0.309 \\
Intervention & \multicolumn{7}{c}{. } & & & &
\end{tabular}

\section{Conclusion and recommendation}

This study has established that increase in farmers' production is determined by their income and farm size. To achieve success in project implementation, it is important that beneficiaries are favourably disposed. Also, programs that meet the felt needs of farmers yield positive results. However, substantial result and sustainability can be impeded by array of challenges. Thus, making program's objectives unrealised. It is recommended that farmers be encouraged to form groups so that they can access credit facility from governments, NGOs or related institutions. There should be sustained continuity in agricultural interventions so that the results acquired could be used as reference to take another intervention.

\section{References}

[1] FAO. (2008). The State of Food Insecurity in the World: High food prices and food security-threats and opportunities. pp 1-2 ftp://ftp.fao.org/docrep/fao/011/i0291e/i0291e00a.pdf

[2] FAO. (2012). Potential Impacts of Climate Change on Food Security in Mali. Rome.

[3] HLPE. (2012). Social protection for food security. A report by the High-Level Panel of Experts on Food Security and Nutrition of the Committee on World Food Security. 
[4] IFPRI (2010). Impact of Farmers Field Schools on Agricultural Productivity and Poverty in East Africa.

[5] Oladoja, M.A., Adedotin, S.E and Adedokun, O.A., (2008). Training Needs of Fisherfolks on Fishing Technologies. Journal of Food, Agriculture, Environment, Science and Technology. Vol 6: No. 1, WFL Publisher, Helsinki, Finland. Available at www.World-Food.net.

[6] Sangotegbe, N. S. (2011). Adaptation strategies to climate change by food crop farmers in OkeOgun, Oyo State, Nigeria. An M. Sc thesis submitted to the Department of AERD, University of Ibadan. pp 43-66

[7] SEA. C. (2013). Monitoring and evaluation for climate change adaptation and resilience: A synthesis of tools, frameworks and approaches - 2nd edition. Retrieved December 13 ${ }^{\text {th }}, 2016$ from http://www.seachangecop.org/node/3258

[8] Shah, M., Fischer, G. and Van-Velthuizen, H. (2008). Food Security and Sustainable Agriculture. The Challenges of Climate Change in Sub-Saharan Africa. Luxemburg: International Institute for Applied Systems Analysis. 